\title{
Customer Relationship Management Implementation and its Implication to Customer Loyalty in Hospitality Industry
}

\author{
Budiono Hardjono $\bowtie$, Lai Pooi San
}

Faculty of Technology Management and Technopreneurship, Universiti Teknikal Malaysia, Melaka, Malaysia

\section{Info Article}

History Article:

Received Desembar 2016

Approved Februari 2017

Published Maret 2017

\section{Keywords:}

Customer Relationship Management; Customer Loyalty; Customer Satisfaction; Customer Oriented; Knowledge Management; Hospitality.

\begin{abstract}
Building up customer loyalty have become more important to survive in the high competition of hospitality industry. One approach to developing this is by implementing customer relationship management (CRM). This study investigates the implication of CRM implementation towards customer loyalty in the hospitality industry. The results should assist marketers to recognize what determinant factors and dimension of CRM that contribute to building up customer loyalty in the hospitality industry. A purposive survey of 150 respondents of all rated hotels in Malacca, Malaysia was conducted. It is found that there is a significant correlation between customer orientation, CRM organization, and knowledge management towards customer loyalty while the another dimension of technology-based CRM has no significant effect on this research. The marketer in the hospitality industry should, however, carefully evaluate the nature of customer loyalty regarding any other variables that are not included such as brand image and brand association and some special or unique features in this hospitality industry that should be addressed in the future research.
\end{abstract}

\section{Implementasi Manajemen Hubungan Pelanggan dan Implikasinya terhadap Loyalitas Pelanggan pada Industri Rumah Sakit}

\begin{abstract}
Abstrak
Membangun loyalitas pelanggan menjadi lebih penting untuk bertahan dalam persaingan industri perhotelan yang tinggi. Salah satu pendekatan untuk pengembangan ini adalah dengan menerapkan customer relationship management (CRM). Penelitian ini meneliti implikasi penerapan CRM terhadap loyalitas pelanggan di industri perhotelan. Hasilnya harus membantu pemasar untuk mengenali faktor penentu dan dimensi CRM apa yang berkontribusi dalam membangun loyalitas pelanggan di industri perhotelan. Sebuah survei purposive terhadap 150 responden dari semua hotel berbintang di Malaka, Malaysia dilakukan. Ditemukan bahwa ada hubungan yang signifikan antara orientasi pelanggan, organisasi CRM, dan manajemen pengetahuan terhadap loyalitas pelanggan sementara dimensi lain dari CRM berbasis teknologi tidak berpengaruh signifikan terhadap penelitian ini. Pemasar dalam industri perhotelan harus, bagaimanapun, dengan hati-hati mengevaluasi sifat loyalitas pelanggan mengenai variabel lain yang tidak termasuk seperti brand image dan asosiasi merek dan beberapa fitur khusus atau unik dalam industri perhotelan ini yang harus ditangani dalam penelitian masa depan.
\end{abstract}

JEL Classification: M3, M31 


\section{INTRODUCTION}

In the business world, marketers recognize that customers are the core of business. This incremental growth in hotel industry forces hoteliers seeks out any possible potential competitive advantage to differentiate itself from competitors.

As all marketers understanding, the customer is the source of profitability. To attract traveler or tourism, improvement of service quality and development of new facilities are the efforts for hotel management achieving better organization performance. To clearly differentiate itself from competitors, marketers do not focus on how to improve the customer satisfaction, but they also try to form a customer loyalty so that it becomes the competitive advantage for the hotel industry.

Today many companies are racing to reestablish their connections to new as well as existing customers to boost long-term customer loyalty. This means that marketers are starting to believe in retaining a customer or building customer loyalty rather than attracting new customer in order can decrease the cost of marketing activities in customer attraction. Therefore, customer loyalty needs to emphasize wider by hoteliers to let customers develop their repurchase behavior.

There are many ways to adopt the loyalty, and the most common are by creating value through customer relationship management (CRM). To gain customer loyalty, CRM becomes the strength of the hotel industry. The capability of CRM is the tool that attracts new customers and retains the existing customers. CRM also can define as a customer-focused business strategy which aims to enhance customer satisfaction and increase their loyalty by offering fast and customized services according to customer request. By using CRM, organizations can develop customer relationship through their better information management.

The concept of CRM has been explored by some researchers mostly for service industry including hospitality industry although it is not in sufficient number. The four dimensions of CRM,-key customer focus, CRM organization, knowledge management, and technology-based CRM- were used to identified how this CRM content can affect to marketing and financial performance of varying industries ( $\mathrm{Sin}$ and Yim, 2005). In more specific, the factors in CRM also positively have relationship toward perceived customer satisfaction and customer loyalty in several types of industry (Basar et al., 2011).

The sustainability of service industry relies on how they can deliver satisfaction to their customers and at the end can form the customer loyalty among them. In the bank industry, it is found that banks should make one-to-one and individualized relationship with their customers, offer privatized services and determine the customers' need to achieve a good level of customers' satisfaction. This means CRM factors can influence the customer satisfaction and loyalty in the service industry.

Although quite many researchers study on CRM in several types of industry but specifically, not so many result lead on how CRM can make its role in hospitality industry The application of CRM practices in hotel industries using the four main CRM dimensions was suggested, and it provides an inclusive framework that is useful for elucidation the blow of CRM dimensions on hotel concert (Sarmaniotis et.al., 2013), but it is not specific enough to explain how CRM can make its role in the hospitality industry. This research is to fill this gap with the focus on how this CRM dimensions can affect to the customer's loyalty.

The main purpose of this study is to investigate the relationship of main dimensions of CRM toward customer loyalty in the hospitality industry. The study also sought to identify whether the demographic factors of the respondents could have a different significant respond to the implementation of CRM in the hospitality industry.

More specifically, the study aimed to achieve the following specific research objectives: To determine whether the policy of customer orientation dimensions in the hospitality 
has a relationship with customer satisfaction and loyalty; To determine whether CRM organization dimensions in hospitality industry has relationship with customer loyalty; To determine whether customer knowledge management dimensions has relationship with customer loyalty; To determine whether Technology-based CRM has relationship with customer loyalty

\section{Hyoothesis Development}

\section{Customer Relationship Management (CRM)}

According to Mohammad et al. (2013), the concept of CRM can be defined in different ways meaning that different thing to different people, depending on context and other contingent factors. Therefore, there is no agreed definition of CRM (Ngai, 2005; Kevork \&Vrechopoulos, 2009; Hamid, 2009).

In previous researches, Kotler and Armstrong (2012) defined CRM as "the overall process of building and maintaining profiTable customer relationships by delivering superior customer value and satisfaction." However, in a more technology-oriented perspective, Zikmund et al. (2003) defined CRM as "a business strategy that using information technology to provide an organization with a comprehensive, reliable and integrated view of its customer base so that all processes and customer interactions help maintain and expand beneficial relationships."

For some researchers, CRM also can be defined as the use of advanced technology involving a database, data warehouse and data mining informed by enterprise's strategies and philosophies to increase customer retention rates and profitability ( $\mathrm{Xu}$ and Walton, 2005; Nguyen et al., 2007). This has been strongly proved that CRM can be the view from multiple perspectives (e.g. people, process, technology, strategy) (Mohammad et al., 2013).

Moreover, Kamakura et al. (2005) classified CRM into two categories: analytical and behavioral CRM. In analytical, CRM has refers to how an enterprise manages the customer's information through customer interaction. While in behavioral, CRM is the integration of various data (e.g. customer past purchases and service records, operations, service logs) to establish a more comprehensive view towards customer purchasing behavior. From these two categories, it has shown that CRM is effectively becoming an advantage in managing long term customer relationship to enhance customer loyalty. While, according to Zablah et al. (2004), the main purpose of CRM is to build and maintain a profiTable customer relationship. Therefore, the creating of CRM activities are mainly focus on building customer loyalty through a sustaining relationship with customers over time.

\section{CRM Components}

Based on past related literature, (Sin et al., 2005) have hypothesized the concept of CRM as a multi-dimensional construct consisting of four broad behavioral components. These components are key customer focus, CRM organization, knowledge management and technologybased CRM. This is in accord with the general notion of successful CRM being implemented based on four key areas: people; processes; strategy; and technology (Fox and Stead, 2001) and the four behavioural dimensions (e.g. key customer focus, CRM organization, knowledge management and technology-based CRM) must interact to enhance long-term organization performance.

In Malaysia content, Abdullateef et al. (2010) identified customer orientation as one of the CRM components that is more comprehensive than key customer focus. Therefore, in several types of research, customer orientation has highlighted as an important component of CRM (Wang et al., 2010) and applying it to studies of relationships between CRM, RM (relationship marketing) and business performance in the hospitality industry ( $\mathrm{Wu}$ and $\mathrm{Lu}, 2012$ ). Also, numerous researchers have highlighted the significant effects of leading studies on CRM components in the hotel industry.

According to Mohammad et al. (2013), CRM components are important as the determinants of organization performance perspectives. In short, the four behavioral components (e.g. customer orientation, CRM organization, 
knowledge management and technology-based CRM) are applied in this study to analyze the relationships on customer loyalty in the hospitality industry.

\section{Customer Orientation}

Customer orientation is referred to the employees' personal work values and attitudes toward their customers (Brown et al., 2002). The aim of customer-oriented behavior is to enhance customer satisfaction and create customer loyalty. The employees' ability to provide a good customer concern ensures a positive impact on organization performance (Kim, 2008). According to Zablah et al. (2012), customer orientation defines as "a work value that captures the extent to which an enduring belief guides employees' job perceptions, attitudes, and behaviors in the importance of customer satisfaction."

From the previous study, (Kim et al., 2006) stated that service firms, like hotels, require a better understanding of customer orientation which can directly improve the service image of the hotel when the employees successfully provide the customer a superior service value. Hence, the opportunity of repurchase and recommendation by current customer increases invisibly (Sarmaniotis et al., 2013).

In the hotel industry, the most vital issue that hotel managers need to focus on is customer interaction. They should pay attention to developing good communication with customers to enhance service experience or service quality. Therefore, researchers have reinforced that customer orientation leads to the improvement of hotel performance and also enhancing the loyalty. As a result, customer orientation is one of the important components of CRM to create loyalty.

\section{CRM Organization}

First and foremost, to make sure there is highly employee involvement to conduct the customer-oriented behaviors. Organizations also have to develop an appropriate working atmosphere for the service in work. As a result, organizations will provide their employees the supportive working conditions with the help of advanced technology and tools, customer satisfaction and complaints management systems, inspiring leadership and reward system to let employees play their role in customer interaction and communication effectively (Mechinda \& Patterson, 2011).

In fact, the most critical part of successful CRM implementation is organizational structure. CRM requires the whole organization to work towards achieving organization goals through building strong customer relationship (Sin et al., 2005). As such, the structure design will optimize customer relationships which are including the development of process teams, customer-oriented teams (Sheth \& Sisodia, 2002), cross-discipline segment teams and cross-functional teams (Ryals \& Knox, 2001). A flexible organizational structure design also helps the hotel manager to reconstruct and generate customercentric values if there is necessary.

In the context of the hospitality industry, the most vital to CRM is the individual employees who are the building blocks of customer relationships (Brown, 2000; Ryals \& Knox, 2001). Also as the $\mathrm{Ku}$ (2010) stated, for CRM success it does not only require technological quality or systems, but it is also requiring a service concept as well as appropriate operation procedures. Thus, this can stress that active involvement of employees in the organization has a direct impact on organization performance and development of long-term beneficial customer relationship to build up the loyalty. Hence, it can be said that CRM organization has to be an essential through which firms affect the fundamental changes in the way they organized their business processes (Sin et al., 2005).

\section{Knowledge Management}

Customer knowledge has been considered as the critical organizational resource. It is about the techniques of transmission of knowledge regarding customers as the core resources that allow a company to strengthen its link with customers and achieve the sustainable competi- 
tive advantages especially in the hotel industry (Shi \& Yip, 2007). When organization cans are effectively transforming customer information into customer knowledge, it means that CRM is predicted to be successful (Mohammad et al., 2013). This is because the success of relationship management is heavily dependent on information collecting and analyzing. Hence, it is stated that key facets of "knowledge management" can include knowledge learning and generation, knowledge dissemination and sharing and knowledge responsiveness (Sin et al., 2005).

By generating knowledge about customers, organizations can effectively use the knowledge to enhance the competitiveness of hotel industry. Through the information gather from customer interaction, the knowledge generated a 360-degree customer view to meet their needs and satisfaction (Sin et al., 2005). Moreover, Hallin and Manburg (2008) also stressed that knowledge management is very important for hospitality in building up sustainable competitive advantages. On another hand, the uses of knowledge is becoming valuable for hotels to meet customer's needs by sharing and disseminating the customer knowledge throughout the organization (Ryals \& Knox, 2001). In fact, for organizations to stay competitive there needs to be wider uses of knowledge in their market, exploring and making use of their existing knowledge about customers to be successful in CRM implementation.

Knowledge responsiveness takes the form of acting on the knowledge generation and dissemination (Sin et al., 2005) which is all the marketing activities or actions taken in achieving customer satisfaction and to creating the ultimate goal of the development of customer relationship, the "loyalty." Hence, Lo et al. (2010) recommended investigating the impact of knowledge management component on the hotel industry in future research.

\section{Technology-based CRM}

Technology plays an important role in CRM performance. According to Dutu and Halmajan (2011), CRM implementation will end in failure if the information technology is not used properly. Thus it is very important for the hotel industry to use the technology correctly to manage the information that gathered from customers.

Consequently, CRM based technology enables organizations retaining customer long-lost and making them more profiTable, because of the customer database and other information-storing systems (Robert et al., 2005) can provide the organization with valuable customer knowledge that will help hotel management to achieve organization goals and enhance hotel performance more effectively. It is clearly stressed that CRM systems can be a failed implemented without the help of information technology.

Additionally, the use of technology in marketing is the greatest opportunity in the hospitality industry because it is very important to get the right information from the right people at the right time so that correct decisions can be made more perfectly (Dev \& Olsen, 2000). In support of that view, Kasim and Minai (2009) stated that CRM technology dimension has a direct impact on hotel performance because the aim of information technology is used to improve performance. Computer technologies such as computer-aided design, flexible manufacturing systems, just-in-time production databases, data warehouse, data mining and CRM software system (e.g. SAP and Oracle) enables organizations to manage customer data and interaction, accessing business information, automate sales, marketing and also the whole hotel supply chain relationships.

\section{Customer Loyalty}

The hotel organizations face growth of volume and pace of competition today has reinforced customer loyalty becomes the hotel's ability to differentiate itself from its competitors. As Majumdar (2005) stated that "Customer loyalty is a complex and multidimensional concept." The complexity has made customer loyalty is hard to be defined in a proper form which can be agreed by everyone. According to Mcmullan 
Budiono Hardjono \& Lai Pooi San / Enhancing Capability of Human Resources...

and Gilmore (2008) as cited in Jacoby and Kyner (1973), there are no overall agreed definition of customer loyalty, the most widely accepted definition is loyalty is described as the biased, behavioural response (i.e. purchase), expressed over time, by having the decision-making unit, with respect to one or more alternative brands out of a set of such brands, and is a function of psychological (i.e. decision-making) process.

However, Oliver (1999) has defined loyalty as "a deeply held commitment to re-buy or re-patronize a preferred product or service consistently in the future, thereby causing the frequency of repeat-purchase to the same brand, despite situational influences and marketing efforts having the potential to cause switching behavior." This definition helps us to distinguish loyalty as attitudinal, behavioral and situational. Attitudinal loyalty is expressed as an attitude that leads to an ongoing relationship with the brand, the strong loyalty that often conditioned on a positive attitude towards the brand (e.g. positive attitude of the consumer to make the repeat purchase to the same preferred brand).

Behavioral loyalty is mainly expressed in terms of consumer behavior on purchasing whereby the consumer has been divided into categories of monogamous (100 percentage loyal), promiscuous (no loyalty to any product or service) and polygamous" (loyal to a brand in specific product line or category) that often conditioned on customer satisfaction (e.g. consumer pattern in past purchases). Lastly, situational loyalty is expressed as the purchase pattern of the consumer is influenced by purchasing situation such as individual's current circumstances and their characteristics (e.g. the desired product or service is too expensive or only available in special season)

In a business context, loyalty describes as a customer's commitment to doing business with a particular organization, by repeatedly purchasing, and recommending the selected product or service to other people (McLlroy \& Barnett, 2000). The aim of loyalty in a successful business is based on a long-term beneficial relationship between customer and enterprise.

The beneficial customer relationship will help firms to win customer loyalty, marketing shares, and profit margin will consistently reduce the necessity costs of acquiring a new customer. Hence, it has strongly reflected that loyalty is more profible in retaining current customer rather than acquiring new customers to increase business growth. Kuusik, (2007) summarized and synthesized all of the factors affecting loyalty complete with all dimension of each content derivatives, Figure 1 indicates all of these factors.

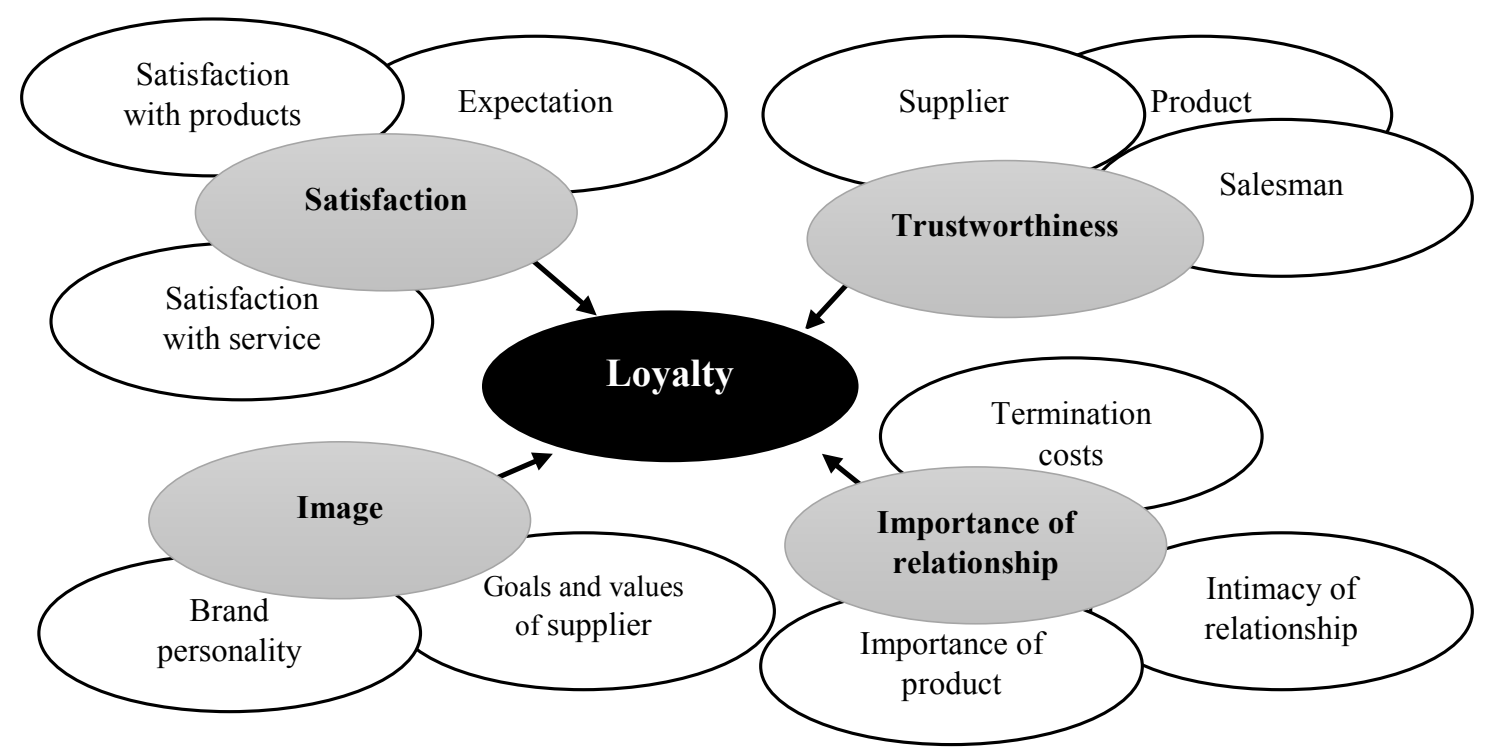

Figure 1. Factors affecting loyalty 
In the CRM implementation context, all factors that affect to loyalty can be inter-related to the CRM dimensions with the explanation as follows. Customer satisfaction-with fulfilled customer expectation dimension-actually is the main objective of customer orientation policy in CRM before at the end it creates customer loyalty. Hence this factor is a mediating variable to customer loyalty. The similar approach also can be made for the factor of trustworthiness which closely inter-relate with CRM organization variable. Salesmanship is one of an indicator how to see this achievement.

The intimacy of a relationship is an indicator of the relationship factor which closely interrelates with the variable of customer knowledge in the CRM concept. Kanchan and Sharma (2015) mentioned the achievement of relationship management is intensively reliant on collecting and analyzing customer in sequence.

Image dimension so much relates with brand personality and brand equity of the company. As one of the main part of marketing activity, building up brand awareness and brand equity is vital to the sustainability of the business. At the end, this direction of brand equity will reach the brand resonance (Keller) where the loyalty of customer will be formed.
Building up brand equity always involve marketing communication, and this cannot be done without using technology. Technology based CRM is one of tool that can be used to achieve this loyalty.Hence the combination of customer loyalty and CRM implementation in the hospitality industry can be proposed as Figure 2. Derived from summary of literature review, the framework of study can be proposed as follows:

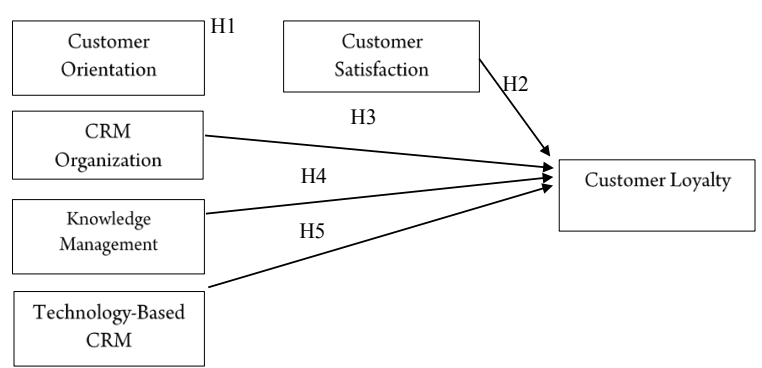

Figure 3. Theoretical Framework Of Study

This study proposes the following hypothesis

$\mathrm{H} 1$ : Customer orientation has a positive relationship with customer satisfaction.

$\mathrm{H} 2$ : Customer satisfaction has positive relationship on customer loyalty

H3: CRM organization has a positive relationship on customer loyalty.

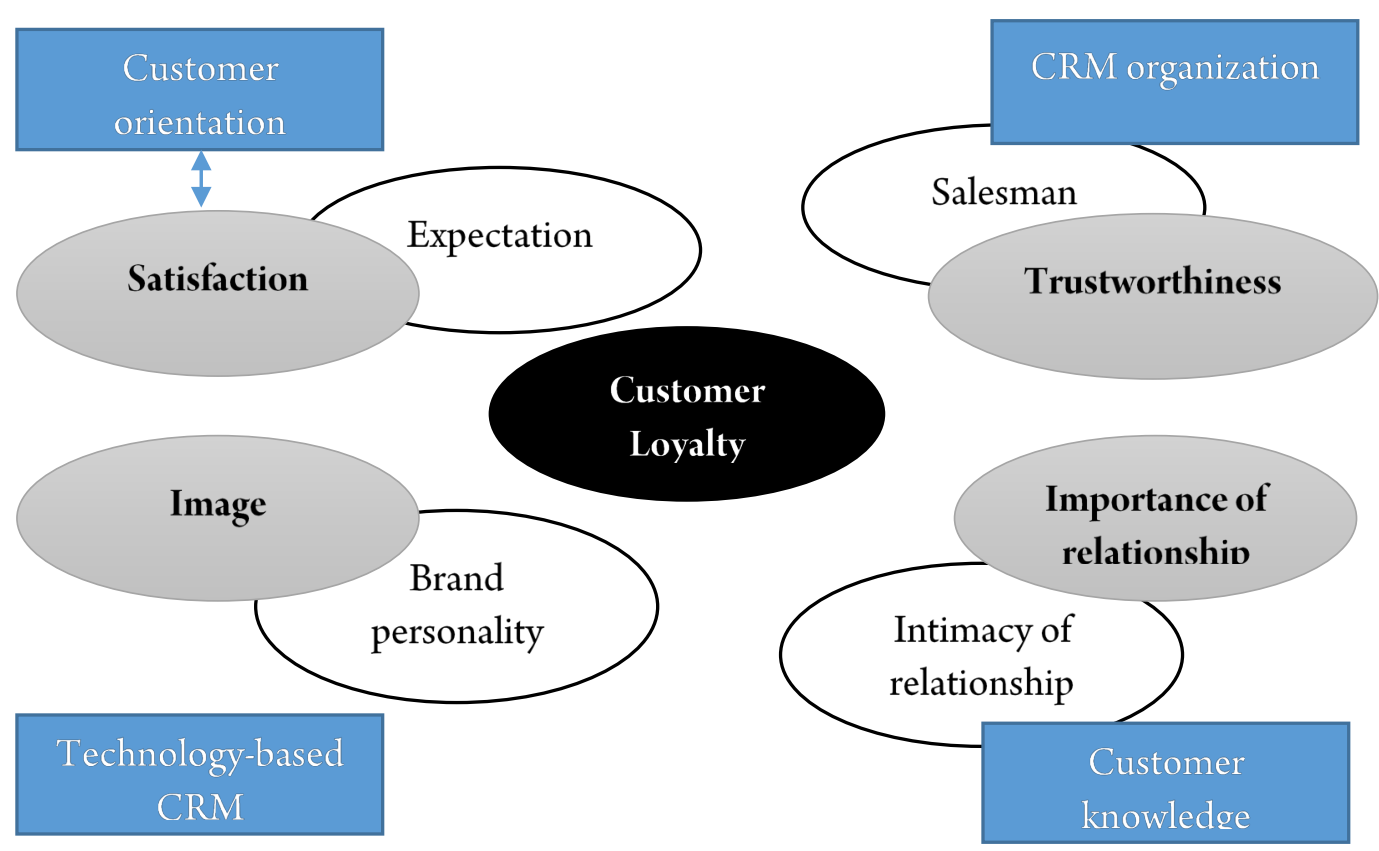

Figure 2. Relationship CRM Development Towards Customer Loyalty In Hospitality Industry 
H4: Knowledge management has a positive relationship on customer loyalty.

H5: Technology-based CRM has positive relationship on customer loyalty

\section{METHOD}

This research used a quantitative methodology, while sampling was determined by using a purposive non-probability method to 150 respondents of hotel management in Melaka. The city of Melaka was chosen because this city is one of the tourist's attractions in Malaysia after it was declared as world heritage city by UNESCO in 2008.

Based on Ministry of Tourism and Culture Malaysia (2015), there are 159 registered hotels in Malacca state. The purposive technique is conducted to select the sample of hotels from unrated to 5 stars hotel to collect the data accurately which is also represent the whole population of hotels in Malacca. The research instrument used is questionnaire which is a tool for collecting primary data under a standardization of questions. In total, there was 150 questionnaires distributed, but only 108 are received with complete answers.

Target respondents chosen are hotel management from unrated to 5 stars hotel in order to collect the data accurately which is also represent the whole population of hotels in $\mathrm{Ma}$ lacca. Table 1 provides a socio-demographic profile of the respondents who participated in the study.

\section{Data Collection}

The initial questionnaire was pretested with a convenience sample of $10-20 \%$ actual sample size using a pilot-test as described by Baker (1994). Data for the main study was collected over a two-month period during AprilMay 2016. There were 150 questionnaires distributed to 30 hotels in Melaka city.

\section{Measurement}

Instruments used in the questionnaire were referred to the previous literature analysis, and five-points Likert-type scales were applied throughout to the questionnaire. The CRM components used as variables are referred to previous researchers as described by $\operatorname{Sin}$ et al. (2014) and Basar et al. (2013). All dimensions of this variables were clearly defined to make easy respondents answer, while all indicators can be found out from the management. Table 2 indicates all these variables, dimensions, and indicators used.

Table 1. A Socio-Demographic Profile of Respondents

\begin{tabular}{|c|c|c|}
\hline & Number (n) & Percentage (\%) \\
\hline \multicolumn{3}{|l|}{ Target respondents: } \\
\hline Hotel management & 108 & 100.0 \\
\hline \multicolumn{3}{|l|}{ Gender: } \\
\hline Female & 76 & 70.4 \\
\hline Male & 32 & 29.6 \\
\hline Total & 108 & 100.0 \\
\hline \multicolumn{3}{|l|}{ Age: } \\
\hline $20-30$ years & 79 & 73.1 \\
\hline $31-40$ years & 18 & 16.7 \\
\hline $41-50$ years & 9 & 8.3 \\
\hline 51 years or older & 2 & 1.9 \\
\hline Total & 108 & 100.0 \\
\hline \multicolumn{3}{|l|}{ Education: } \\
\hline SPM & 13 & 12.0 \\
\hline STPM/Diploma & 19 & 17.6 \\
\hline Degree & 76 & 70.4 \\
\hline Master/Ph.D. & 0 & 0.0 \\
\hline Total & 108 & 100.0 \\
\hline \multicolumn{3}{|l|}{ Position: } \\
\hline General Manager & 34 & 31.5 \\
\hline Marketing Manager & 5 & 4.6 \\
\hline Supervisor & 11 & 10.2 \\
\hline Staff & 58 & 53.7 \\
\hline Total & 108 & 100.0 \\
\hline
\end{tabular}

Customer orientation was measured with three dimensions: Value for customers, organization understanding to customer needs, and commitment to customer needs, while the indicator for these measurements is customer satisfaction. CRM organization has two dimensions: trustworthiness and employee performance 
Table 2. Measurement

\begin{tabular}{|c|c|c|}
\hline Variable & Dimension & Indicator \\
\hline $\begin{array}{l}\text { Customer orienta- } \\
\text { tion }\end{array}$ & $\begin{array}{l}\text { Value for customers } \\
\text { Company understanding to customer needs }\end{array}$ & $\begin{array}{l}\text { Index customer satisfac- } \\
\text { tion and complaint rate }\end{array}$ \\
\hline Customer satisfaction & $\begin{array}{l}\text { Commitment to customer needs } \\
\text { Relationship level between organization and } \\
\text { customers } \\
\text { Sustainable communication between organiza- } \\
\text { tion and customers }\end{array}$ & Complaint rate \\
\hline $\begin{array}{l}\text { Knowledge manage- } \\
\text { ment }\end{array}$ & $\begin{array}{l}\text { Responsiveness to customer's } \\
\text { needs based on knowledge of customer } \\
\text { Two ways communication with customers } \\
\text { based on knowledge of customers } \\
\text { The way to handle service and expectation } \\
\text { based on knowledge of customer }\end{array}$ & $\begin{array}{l}\text { Rate of intimacy of em- } \\
\text { ployees with customers } \\
\text { is getting better }\end{array}$ \\
\hline $\begin{array}{l}\text { Technology-based } \\
\text { CRM }\end{array}$ & $\begin{array}{l}\text { Technology used in increasing awareness of } \\
\text { company to customers } \\
\text { Customized and individualized information to } \\
\text { customers }\end{array}$ & $\begin{array}{l}\text { The brand awareness } \\
\text { and proudness of cus- } \\
\text { tomers to become a } \\
\text { member of preference }\end{array}$ \\
\hline Customer loyalty & $\begin{array}{l}\text { High brand personality perception by customer } \\
\text { Strong attitude and positive belief toward } \\
\text { brand } \\
\text { The influence of community, membership and } \\
\text { identity } \\
\text { Satisfactory experience to brand }\end{array}$ & $\begin{array}{l}\text { community } \\
\text { The rate of repeat pur- } \\
\text { chase }\end{array}$ \\
\hline
\end{tabular}

based on how organization understands to meet their customers' needs. All these dimensions can be indicated by its salesmanship performance of the employees.

Knowledge management consists of three dimensions: Responsiveness to customers, two ways communication, and the way to handle services. The indicator of this dimension is the rate of intimacy between customers and organization. Technology-based CRM can be measured by the technology used, customization and brand personality.

Customer satisfaction is mediating variable for customer loyalty. Its dimension consist of relationship and sustainable communication between organization and customers while customer loyalty has three dimensions: positive belief, influence to the community and satisfactory experience to the brand. Indicator for this variable is the rate of repeat purchase.

\section{RESULT AND CONCLUSION}

\section{Interest in CRM Implementation}

Organization interest in CRM implementation is not significantly different by gender, but they are different by position and education as indicated by Figure 4, 5, 6, and 7. Either female or male has almost similar understanding about the important of CRM but the higher position and education, the more interest for them to understand about the CRM.

\section{PERCENTAGE OF TOTAL 108 \\ RESPONDENTS BY GENDER}

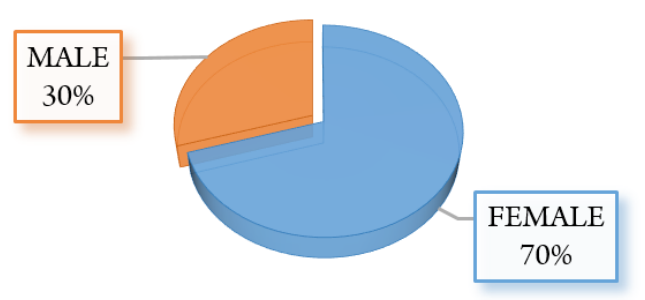

Figure 4. Gender of respondent 
Budiono Hardjono \& Lai Pooi San / Enhancing Capability of Human Resources...

INTEREST IN CRM BY GENDER

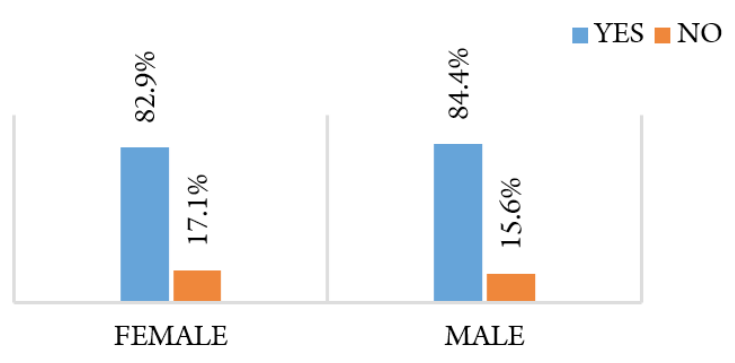

Figure 5. CRM by gender

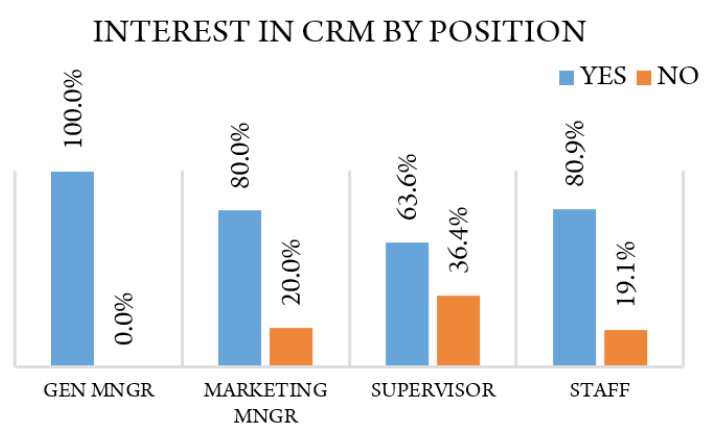

Figure 6. CRM by position
INTEREST IN CRM BY EDUCATION

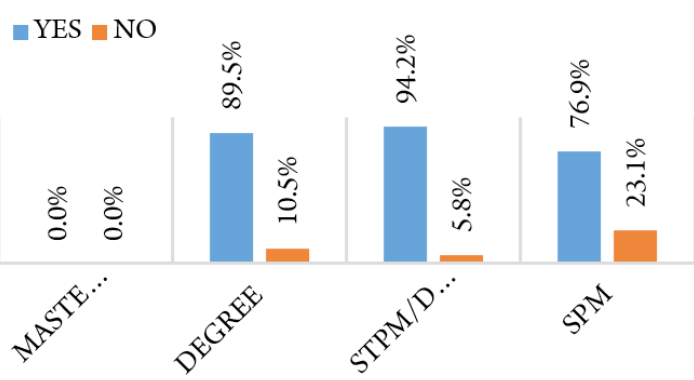

Figure 7. CRM by education

This result is very logic since the understanding of management implementation needs high education at least at the diploma or degree level. In this research, no master and Ph.D. level manager were involved in the survey.

\section{Customer Satisfaction as Mediation Variable}

As depicted in Figure 3, customer orientation policy in hospitality industry theoretical-

Table 3. Correlations

\begin{tabular}{llll}
\hline & & Custm. Orientation & Cust. Satisfaction \\
& Pearson Correlation & 1 & $.587^{* *}$ \\
\cline { 2 - 4 } Custm. Orientation & Sig. (2-tailed) & & .000 \\
& $\mathrm{~N}$ & 108 & 108 \\
& Pearson Correlation & $.587^{* *}$ & 1 \\
Cust. Satisfaction & Sig. (2-tailed) & .000 & \\
& $\mathrm{~N}$ & 108 & 108 \\
\hline
\end{tabular}

**. Correlation is significant at the 0.01 level (2-tailed).

Table 4. Model Summary

\begin{tabular}{lllll}
\hline Model & $\mathbf{R}$ & R Square & Adjusted R Square & Std. Error of the Estimate \\
\hline 1 & $.587^{\mathrm{a}}$ & .345 & .338 & .58870 \\
\hline \multicolumn{2}{l}{ a. Predictors: (Constant), Custm. Orientation }
\end{tabular}

Table 5. ANOVA $^{\mathrm{A}}$

\begin{tabular}{lllllll}
\hline Model & & Sum of Squares & Df & Mean Square & F & Sig. \\
\hline \multirow{3}{*}{1} & Regression & 19.311 & 1 & 19.311 & 55.721 & $.000^{\mathrm{b}}$ \\
\cline { 2 - 7 } & Residual & 36.736 & 106 & .347 & & \\
\hline
\end{tabular}

a. Dependent Variable: Cust. Satisfaction 
Table 6. Coefficients

\begin{tabular}{|c|c|c|c|c|c|}
\hline \multirow{2}{*}{$\begin{array}{l}\text { Model } \\
\text { B }\end{array}$} & & Unstandardized Coefficients & Standardized Coefficients & \multirow[t]{2}{*}{$\mathbf{t}$} & \multirow[t]{2}{*}{ Sig. } \\
\hline & & Std. Error $\quad$ Beta & & & \\
\hline & (Constant) & 1.664 & & 5.094 & \\
\hline 1 & $\begin{array}{l}\text { Custm. Orienta- } \\
\text { tion }\end{array}$ & 0.609 & 0.587 & 7.465 & \\
\hline
\end{tabular}

a. Dependent Variable: Cust. Satisfaction

Table 7. T Test For Variable

\begin{tabular}{llllll}
\hline Variable & Coefficients & Sig. & Df & T calc. & T Table \\
\hline Customer Orientation & 0.609 & 0.01 (two tails) & 107 & 7.465 & 1.6592 \\
\hline
\end{tabular}

ly is not directly affect to customer loyalty, but there is a mediation variable between them called as customer satisfaction. The main objective of customer orientation policy in this industry is to fulfill customer expectation then at the end achieve customer satisfaction.

How close three dimensions measured the correlation ship between customer orientation and customer satisfaction; value for customers, company understanding, and commitment to customer needs. From SPSS result this correlation ship as indicated by Person Correlation as shown in Table 3. Pearson correlation 0.587 at the 0.01 significant level indicates that correlation between customer orientation and customer satisfaction is quite strong. The analysis further the relationship between these two variables using regression, resulted in Table Model Summary, Anova and coefficient regression as shown in Table 4 and 5 .

The value of $R$ square 0.345 in Table 3 indicates that this customer orientation variable can explain the variance of the output. By using t-test, the regression coefficient of customer orientation was checked whether it significantly has a relationship with customer satisfaction. The result on test is shown in Table 7.

Due to $t$ calculated $>t$ Table, so regression coefficient of the independent variable is significant enough to affect the dependent variable, thus Hypothesis $\mathrm{H} 1$ is accepted. Hence customer orientation has a positive relationship on customer satisfaction.
Refer to Table 6 and the basic equation of regression, the relationship expression between these two variables can be derived as follow:

$$
\mathrm{Y}=0.609 \mathrm{X}+1.644
$$

Whereas:

$\mathrm{Y}=$ Customer satisfaction

$\mathrm{X}=$ Customer orientation

\section{Final Result on Effect of Independent Variables toward Dependent Variable}

While customer satisfaction is proven as mediation variables to customer loyalty, now it is needed to assume that this mediation variable is also as similar as the other independent variables that affect to the dependent variable, customer loyalty. Firstly, all of these independent variables need to be checked its correlation to the dependent variable. Table 8 , shows the results on all of the correlation between predictors and dependent variable.

Except for factor of technology-based CRM, the other factors such as customer satisfaction, CRM organization, and knowledge management have a strong correlation to the dependent variable. It can be indicated by the value number of Person correlation of 0.835 , 0.4303 , and 0.465 for customer satisfaction, CRM organization, and knowledge management respectively. All of these values are significant at 0.01 level (two tails). On the other hand, the Pearson correlation for technology-based 
CRM is very low (0.123) and not significant enough either at level 0.01 or 0.05 (two tails). To find out whether these variables have affect significantly to the dependent variable, multiple regression analysis was conducted. Table 9, 10, and 11 show all of this analysis results.

Using multiple regression analysis, 73.9 percent of the variance in customer loyalty can be explained by it predictors: customer satisfaction, CRM organization, knowledge management, and technology-based CRM. But they all need to be cross-checked whether each of them has positive relationship as strong as their regression coefficient to dependent variable as per indicated in Table 11.

\section{Result on Hypothesis Test}

Combine all of the results from regression analysis; hypothesis is checked whether they can be accepted or rejected. The statistical test used here is t-Test as shown in Table 12.

If $\mathrm{t}$-calculated $>\mathrm{t}$-Table, reject $\mathrm{HO}$ and if $\mathrm{t}$-calculated $<\mathrm{t}$-Table accept H0. Table 13 shows all results on this t-test. Technology-

Table 8. Correlations All Of The Predictors

\begin{tabular}{|c|c|c|c|c|c|c|}
\hline & & $\begin{array}{l}\text { Cust. } \\
\text { Satisfac- } \\
\text { tion }\end{array}$ & $\begin{array}{l}\text { CRM. } \\
\text { Organiza- } \\
\text { tion }\end{array}$ & $\begin{array}{l}\text { Knowl- } \\
\text { edge. } \\
\text { Mngm }\end{array}$ & $\begin{array}{l}\text { Tech. } \\
\text { Based. } \\
\text { CRM }\end{array}$ & $\begin{array}{l}\text { Custm. } \\
\text { Loyalty }\end{array}$ \\
\hline \multirow{3}{*}{ Cust. Satisfaction } & Pearson Corre- & 1 & $0.312^{* *}$ & $0.451^{* *}$ & 0.168 & $0.835^{* *}$ \\
\hline & $\begin{array}{l}\text { lation } \\
\text { Sig. (2-tailed) }\end{array}$ & & 0.001 & 0.000 & 0.081 & 0.000 \\
\hline & $\mathrm{N}$ & 108 & 108 & 108 & 108 & 108 \\
\hline \multirow{3}{*}{ CRM. Organization } & $\begin{array}{l}\text { Pearson Corre- } \\
\text { lation }\end{array}$ & $0.312^{* *}$ & 1 & $0.321^{* *}$ & $0.224^{*}$ & $0.403^{* *}$ \\
\hline & Sig. (2-tailed) & .001 & & 0.001 & 0.020 & 0.000 \\
\hline & $\mathrm{N}$ & 108 & 108 & 108 & 108 & 108 \\
\hline \multirow{3}{*}{ Knowledge. Mngm } & Pearson Corre- & $0.451^{* *}$ & $0.321^{* *}$ & 1 & $0.654^{* *}$ & $0.465^{* *}$ \\
\hline & $\begin{array}{l}\text { lation } \\
\text { Sig. (2-tailed) }\end{array}$ & .000 & 0.001 & & 0.000 & 0.000 \\
\hline & $\mathrm{N}$ & 108 & 108 & 108 & 108 & 108 \\
\hline \multirow{3}{*}{ Tech. Based. CRM } & $\begin{array}{l}\text { Pearson Corre- } \\
\text { lation }\end{array}$ & 0.168 & $0.224^{*}$ & $0.654^{* *}$ & 1 & 0.123 \\
\hline & Sig. (2-tailed) & .081 & 0.020 & 0.000 & & 0.205 \\
\hline & $\mathrm{N}$ & 108 & 108 & 108 & 108 & 108 \\
\hline \multirow{3}{*}{ Custm. Loyalty } & $\begin{array}{l}\text { Pearson Corre- } \\
\text { lation }\end{array}$ & $0.835^{* *}$ & $0.403^{* *}$ & $0.465^{* *}$ & 0.123 & 1 \\
\hline & Sig. (2-tailed) & 0.000 & 0.000 & 0.000 & 0.205 & \\
\hline & $\mathrm{N}$ & 108 & 108 & 108 & 108 & 108 \\
\hline
\end{tabular}

**. Correlation is significant at the 0.01 level (2-tailed).

* Correlation is significant at the 0.05 level (2-tailed).

Table 9. Model Summary For Multiple Regression

\begin{tabular}{lllll}
\hline Model & R & R Square & Adjusted R Square & Std. Error of the Estimate \\
\hline 1 & $0.860^{\text {a }}$ & 0.739 & 0.729 & 0.34828 \\
\hline $\begin{array}{l}\text { a. Predictors: (Constant), } \\
\text { Mngm }\end{array}$ & Tech. Based. CRM, Cust. Satisfaction, CRM. Organization, Knowledge.
\end{tabular}


Table 10. Multiple Regression Anova ${ }^{a}$

\begin{tabular}{lllllll}
\hline Model & & $\begin{array}{l}\text { Sum } \\
\text { Squares }\end{array}$ & of df & Mean Square & F & Sig. \\
\hline \multirow{3}{*}{1} & Regression & 35.358 & 4 & 8.840 & 72.874 & $0.000^{\mathrm{b}}$ \\
& Residual & 12.494 & 103 & 0.121 & & \\
\hline & Total & 47.852 & 107 & & & \\
\hline
\end{tabular}

a. Dependent Variable: Custm. Loyalty

b. Predictors: (Constant), Tech. Based. CRM, Cust. Satisfaction, CRM. Organization, Knowledge. Mngm

Table 11. Regression Coefficients

\begin{tabular}{|c|c|c|c|c|c|c|}
\hline \multirow{3}{*}{\multicolumn{2}{|c|}{$\begin{array}{l}\text { Model } \\
\text { B }\end{array}$}} & \multirow{2}{*}{\multicolumn{2}{|c|}{$\begin{array}{l}\text { Unstandardized } \\
\text { Coefficients }\end{array}$}} & \multirow{3}{*}{$\begin{array}{l}\text { Standardized } \\
\text { Coefficients }\end{array}$} & \multirow[t]{3}{*}{$\mathbf{t}$} & \multirow[t]{3}{*}{ Sig. } \\
\hline & & & & & & \\
\hline & & Std. Error & Beta & & & \\
\hline \multirow{5}{*}{1} & (Constant) & 0.299 & 0.382 & & 0.782 & 0.436 \\
\hline & Cust. Satisfaction & 0.673 & 0.054 & 0.729 & 12.414 & 0.000 \\
\hline & CRM. Organization & 0.237 & 0.086 & 0.150 & 2.754 & 0.007 \\
\hline & Knowledge. Mngm & 0.158 & 0.062 & 0.193 & 2.553 & 0.012 \\
\hline & Tech. Based. CRM & -0.167 & 0.071 & -0.159 & -2.346 & 0.021 \\
\hline
\end{tabular}

a. Dependent Variable: Custm. Loyalty

Table 12. T-Test for Hypothesis

\begin{tabular}{llllll}
\hline Variable & Coefficients & Sig. $(2$ tails $)$ & df & T calculated & T Table \\
\hline Cust. Satisfaction & 0.673 & 0.01 & & 12.414 & \\
CRM Organization & 0.237 & 0.01 & 103 & 2.754 & 1.6595 \\
Knowledge Management & 0.158 & 0.01 & & 2.553 & \\
Technology-Based CRM & -0.167 & 0.05 & & -2.234 & 1.9833 \\
\hline
\end{tabular}

based CRM variable is not valid and should be neglected since its confident level cannot achieve 95\% level. Based on Table 7, 11, and 12, the final result on Hypothesis test can be concluded as follow: Hence from this research, it is proven that:

$\mathrm{H} 1$ : Customer orientation has a positive relationship on customer satisfaction.

$\mathrm{H} 2$ : Customer satisfaction has a positive relationship on customer loyalty.

H3: CRM organization has a positive relationship on customer loyalty.

H4: Knowledge management has a positive relationship on customer loyalty.

H5: Technology-based CRM has no positive relationship on customer loyalty.

\section{Regression Model}

Using all of the regression coefficients that already tested their validity, so a multi-linear regression model can be used to estimate the implication of independent variables to dependent variable as follow:

$$
y^{\prime}=0.673 x_{1}+0.273 x_{2}+0.158 x_{3}+0.299
$$

Where as:

$\mathrm{y}^{\prime}=$ Customer satisfaction

$\mathrm{x}_{1}=\mathrm{CRM}$ organization

$\mathrm{x}_{2}=$ Knowledge management

$\mathrm{x}_{3}=$ Technology-based CRM 
Budiono Hardjono \& Lai Pooi San / Enhancing Capability of Human Resources...

Table 13. Final Result On Hypothesis Test

\begin{tabular}{llll}
\hline Variables & Coefficient & T-test result & Final Result \\
\hline Cust. Orientation & 0.609 & T calc $>$ t Table & Accept H1; Reject Ho \\
Cust. Satisfaction & 0.673 & T calc $>$ t Table & Accept H2; Reject Ho \\
CRM Organization & 0.237 & T calc $>$ t Table & Accept H3; Reject Ho \\
Knowledge Management & 0.158 & T calc $>$ t Table & Accept H5; Reject Ho \\
Technology-Based CRM & -0.167 & T calc $<$ t Table & Accept Ho; Reject H5 \\
\hline
\end{tabular}

The involvement of technology in CRM has a very important role as described by Dutu and Hamajan (2011), Robert et al. (2005), and Dev and Olsen, (2000), but in this research results, this factor didn't indicate a significant effect on the creation of customer loyalty. Although the indicators were defined quite clear maybe most of the respondent responded that hospitality industry is not a technology focused business such as an engineering service business or hi-tech entertainment service business. That is why they did not respond enthusiastically when they asked whether this is one of the factor in the CRM that affect to customer loyalty creation.

The composition of respondent could also influence the understanding of technology importance in CRM by position. Mostly the position of respondents is staff and supervisors which include of $64 \%$ from total respondents. The higher position, the better result on employee interest about CRM as depicted in Figure 6.

The value of a coefficient number of independent variables relates to the level of implication to customer loyalty creation. The higher coefficient number, the higher impact. Meaning management should focus on the factors that have a significant impact if they want to increase the level of customer loyalty in this area of business.

\section{CONCLUSION AND RECOMMENDATION}

There are many ways to adopt the customer loyalty creation in the hospitality industry, but the most common are by creating value through customer relationship management (CRM). This approach can retain the existing loyal customers and attract new customers that recommended by this loyal customer or the community between them.

In this research, four factors in the CRM were proven that have an impact on the creation of customer loyalty. These factors are customer orientation, customer satisfaction, CRM organization, and knowledge management. One factor, technology based CRM was not proven and factor that impact to customer loyalty.

Referring to the multiple regression models developed, management should focus to control these main factors based on bigger impact factors that indicated by its coefficient number such as customer satisfaction, CRM organization, and knowledge management respectively.

There is a significant effect on the composition of employee education toward the understanding how important CRM to the hospitality business. The higher education they have, the better understanding of CRM they have.

\section{REFERENCES}

Abdullateef, A. O., Mokhtar, S. S \& Yusoff, R. Z. 2010. The impact of CRM dimensions on call center performance. International Journal of Computer Science and Network Security. 10 (12):184-195.

Baker, T. L. 1994. Doing Social Research ( $\left.2^{\text {nd }} e d\right)$. New York: McGraw-Hill Inc.

Basar, O., Sezgin, S \& Ozok, A. F. 2011. A measurement tool for customer relationship management processes. Industrial Management b 
Data Systems. 111 (6): 943-960.

Brown, T. J., Mowen, J. C., Donavan, D. T \& Licata, J. W. 2002. The customer orientation of service workers: Personality trait effects on self and supervisor performance ratings. Journal of Marketing Research. 39 (1): 110-9.

Dev, C. S \& Olsen, M. 2000. Marketing challenges for the next decade. Cornell Hotel and Restaurant Administration Quarterly. 41 (1):41-47.

Dutu, C \& Halmajan, H. 2011. The Effect of Organizational Readiness on CRM and Business Performance. International Journal of Computers. 1 (2): 106-114.

Fox, T \& Stead, S. 2001. Customer relationship management: delivering the benefits. White Paper, CRM (UK) and SECOR Consulting. New Malden, available at: www.iseing. org/ emcis/EMCISWebsite/EMCIS2011\%20 Proceedings/SCI10.pdf (accessed July 24, 2011).

Hallin, C. A \& Marnburg, E. 2008. Knowledge management in the hospitality industry: a review of empirical research. Tourism Management. 29 (2): 366-381.

Hamid, H. 2009. Toward unfolding CRM implementation in Pakistan: A case study. $17^{\text {th }}$ European Conference on Information Systems. Retrieved on 28 June 2011 from http://is2. lse.ac.uk/asp/aspecis/20090249.pdf

Jacoby, J \& Kyner, D. B. 1973. Brand loyalty vs. repeat purchasing behavior. Journal of Marketing Research. 10: 1-9.

Kamakura, Wagner A., Vikas Mittal, Fernando de Rosa \& Jose Afonso Mazzon. 2005. "Assessing the Service Profit Chain," Marketing Science. 21 :294-317.

Kasim, A \& Minai, B. 2009. Linking CRM strategy, customer performance measure and performance in the hotel industry. International Journal of Economics and Management. (2): 297-316.

Kevork, E. K \& Vrechopoulos, A.P. 2009. CRM literature: conceptual and functional insights by keyword analysis. Marketing Intelligence ${ }^{2}$ Planning. 27 (1): 48-85.

Kim, B. Y. 2008. Mediated Effects of Customer Orientation on Customer Relationship Management Performance. International Journal ofHospitality and Tourism Administration. 9 (2): 192-218.

Kim, S. Y., Jung, T. S., Suh, E. H \& Hwang, H. S.
2006. Customer segmentation and strategy development based on customer lifetime value: a case study. Expert Systems with A p plications. 31 (1): 101-107.

Kotler, P \& Armstrong, G. 2012. Principles of Marketing (12th ed.). Englewood Cliffs, NJ: Prentice-Hall.

Ku, E. C. S. 2010. The Impact of Customer Relationship Management through Implementation of Information Systems. Total Quality Management and Business Excellence. 21 (11): 1085-1102.

Kuusik, A. 2007. Affecting Customer Loyalty: Do Different Factors Have Various Influences in Different Loyalty Levels? Tartu University Press No. 366

Lo, A.S., Stalcup, L. D \& Lee, A. 2010. Customer relationship management for hotels in $\mathrm{H}$ o $\mathrm{n} \mathrm{g}$ Kong. International Journal of Contemporary Hospitality Management. 22 (2): 139-159.

Majumdar, A. 2005. A model for customer loyalty for retail stores inside shopping malls-an Indian perspective. Journal of Services ResearchSpecial Issue, December: 47-64.

Mcllroy, A \& Barnett, S. 2000. Building customer relationships: do discount cards work?. Managing Service Quality: An International Journal. 10 (6): 347-355.

McMullan, R \& Gilmore, A. 2008.Customer loyalty: an empirical study. European Journal of Marketing. 42 (9/10): 1084-1094.

Mechinda, P \& Patterson, P. G. 2011. The impact of service climate and service provider personality on employees' customer-oriented behavior in a high-contact setting. Journalof Services Marketing. 25 (2): 101-113.

Mohammad, A. A., Rashid, B. B \& Tahir, S. B., 2013. Assessing the influence of customer relationship management (CRM) dimensions on organization performance. Journal of Hospitality and Tourism Technology. 4 (3): 228-247.

Ngai, E. W. T. 2005. Customer relationship management research (1992-2002). Marketing Intelligence \& Planning, 23 (6) : 582-605.

Nguyen, T., Sherif, J \& Newby, M. 2007. Strategies for successful CRM implementation. Information Management \& Computer Security. 15 (2): 102-115.

Oliver, R. L. 1999. Whence consumer loyalty?. Journal of Marketing. 63: 33-44. 
Budiono Hardjono \& Lai Pooi San / Enhancing Capability of Human Resources...

Roberts, M., Liu, R \& Hazard, K. (2005). Strategy, technology, and organizational alignment: key components of CRM success. Journal of Database Marketing and Customer Strategy Management. 12 (4): 315-26.

Ryals, L \& Knox, S. 2001. Cross-functional issues in the implementation of relationship marketing through customer relationship management. European Management Journal. 19 (5): 534-42.

Sarmaniotis, C., Assimakopoulos, C \& Papaioannou, E. 2013. Successful implementation of CRM in luxury hotels: determinants and measurements. Euromed Journal of Business. 8 (2): 134-153.

Sheth, J. N \& Sisodia, R. S. 2002. Marketing productivity: issues and analysis. Journal of Business Research. 55 (5): 349-62.

Shi, J \& Yip, L. 2007. Driving innovation and improving employee capability: the effects of customer knowledge sharing on CRM. The Business Review. 7 (1): 107-112.

Sin, L. Y. M., Tse, A. C. B \& Yim, F. H. K. 2005. CRM: conceptualization and scale development. European Journal of Marketing. 39 (11/12): 1264-1290.
Tourism Malaysia. 2015. Statistics. Retrieved from 12 December 2015 from http://corporate. yourism.gov.my/statistics

Wang, C., Huang, Y., Chen, C \& Lin, Y. (2010), "The influence of customer relationship management process on management performance", International Journal of Organizational Innovation. 2 (3): 40-51.

$\mathrm{Wu}, \mathrm{S}$. I \& Lu, C. 2012, "The relationship between CRM, RM, and business performance: a study of the hotel industry in Taiwan", International Journal of Hospitality Management. 31: 276-285.

Xu, M. X \& Walton, J. 2005. Gaining customer knowledge through analytical CRM. Indus trial Management \& Data Systems. 105 (7): 955-971.

Zablah, A. R., Franke, G. R., Brown, T. J \& Bartholomew, D.E. 2012. How and when does customer orientation influence frontline employee job outcomes? A meta-analytic evaluation. Journal of Marketing. 76 (3): 21-40.

Zikmund, W. G., McLeod Jr., R \& Gilbert, F. W. 2003. Customer Relationship Management: Integrating Marketing Strategy and Information Technology. New Jersey: Wiley. 